\title{
YIELD AND BIOMETRIC CHARACTERISTICS OF MAIZE SUBMITTED TO PLANT POPULATION AND TRINEXAPAC-ETHYL DOSES ${ }^{1}$
}

\author{
LUIZ FERNANDO PRICINOTTO ${ }^{2}$, CLAUDEMIR ZUCARELI $^{3}$, ANDRÉ SAMPAIO FERREIRA $^{3 *}$, LEANDRO \\ TEODOSKI SPOLAOR ${ }^{4}$, INÊS CRISTINA DE BATISTA FONSECA ${ }^{3}$
}

\begin{abstract}
The use of plant growth regulators in agriculture can alter the morphology of corn plants, increasing crop yield due to the possibility of increasing the population. This study aimed to evaluate the effects of plant populations associated with trinexapac-ethyl (TE) doses on the biometric characteristics of shoot and grain yield of contrasting corn cultivars regarding plant architecture. Experiments were conducted in the field during two seasons with the hybrids 2B710 HX (flat leaf) and TL Status (erect leaf) in a randomized block design (four replications) and treatments in a $5 \times 5$ factorial scheme, with five plant populations (40, 60, 80,100 , and 120 thousand plants $\left.\mathrm{ha}^{-1}\right)$ and five TE doses $\left(0,100,200,300\right.$, and $\left.400 \mathrm{~g} \mathrm{a.i.} \mathrm{ha}^{-1}\right)$ applied by foliar spraying at the V6 stage. Plant height, ear insertion height, stem diameter, leaf area index, and grain yield were evaluated. An increment in population increases plant height, ear insertion height, and the leaf area index, but reduces stem diameter. The plant growth regulator TE reduces plant height and ear insertion height. The interaction between plant population and TE favors corn yield, with the highest values observed in combinations of 93.4 thousand plants $\mathrm{ha}^{-1}$ with a dose of $176 \mathrm{~g} \mathrm{ha}^{-1}$ of TE for the hybrid 2B710 $\mathrm{HX}$ and 92.2 thousand plants ha ${ }^{-1}$ with a dose of $251 \mathrm{~g} \mathrm{ha}^{-1}$ of TE for the hybrid Status TL.
\end{abstract}

Keywords: Self-shading. Plant density. Growth regulator. Zea mays L.

\section{PRODUTIVIDADE E CARACTERÍSTICAS BIOMÉTRICAS DO MILHO SUBMETIDO A POPULAÇÕES DE PLANTAS E DOSES DE TRINEXAPAC-ETHYL}

\begin{abstract}
RESUMO - O uso de biorreguladores na agricultura pode alterar a morfologia das plantas de milho, aumentando a produtividade da cultura pela possibilidade do incremento populacional. O trabalho objetivou avaliar os efeitos de populações de plantas associadas às doses de trinexapac-ethyl (TE) sobre as características biométricas da parte aérea e a produtividade de grãos de cultivares de milho contrastantes quanto à arquitetura de plantas. Experimentos foram conduzidos a campo, em duas safras, com os híbridos 2B710 HX (folha plana) e Status TL (folha ereta), utilizando blocos casualizados (quatro repetições) com tratamentos em esquema fatorial 5 x 5, sendo cinco populações de plantas $\left(40 ; 60 ; 80 ; 100\right.$ e 120 mil plantas ha $\left.{ }^{-1}\right)$ e cinco doses de TE $\left(0 ; 100 ; 200 ; 300\right.$ e $400 \mathrm{~g}$ de i.a. ha $\left.^{-1}\right)$, aplicadas via pulverização foliar no estádio V6. Foram avaliadas as alturas de plantas e de inserção da espiga, o diâmetro do colmo, o índice de área foliar e a produtividade de grãos. O incremento na população aumenta a altura de plantas, a inserção da espiga e o índice de área foliar, porém reduz o diâmetro do colmo. O biorregulador TE reduz as alturas de plantas e de inserção da espiga. A interação de população de plantas e TE favorece a produtividade do milho, com maiores valores observados nas combinações de 93,4 mil plantas ha-1 com a dose de $176 \mathrm{~g} \mathrm{ha}^{-1}$ de TE para o híbrido 2B710 HX e 92,2 mil plantas $\mathrm{ha}^{-1}$ com a dose de $251 \mathrm{~g} \mathrm{ha}^{-1}$ de TE para o híbrido Status TL.
\end{abstract}

Palavras-chave: Aussombreamento. Densidade de plantas. Regulador de crescimento. Zea mays L.

\footnotetext{
${ }^{*}$ Corresponding author

${ }^{1}$ Received for publication in $05 / 21 / 2018$; accepted in $04 / 16 / 2019$.

Paper extracted from the doctoral thesis of the first author.

${ }^{2}$ Department of Agricultural Development, Secretaria de Estado da Agricultura e do Abastecimento, Cianorte, PR, Brazil; 1fpricinotto@hotmail.com - ORCID: 0000-0003-2600-8564.

${ }^{3}$ Postgraduate Program of Agronomy, Universidade Estadual de Londrina, Londrina, PR, Brazil; claudemircca@uel.br - ORCID: 00000002-5260-0468, andresampaioferreira@gmail.com - ORCID: 0000-0002-8224-9269, inescbf@uel.br - ORCID: 0000-0003-0129-8534.

${ }^{4}$ Postgraduate Program of Genetics and Breeding, Universidade Estadual de Maringá, Maringá, PR, Brazil; leandrotspolaor@hotmail.com ORCID: 0000-0002-7704-7400.
} 


\section{INTRODUCTION}

Corn is one of the most efficient species in the conversion of radiant energy into biomass (SANGOI et al., 2007). The adequacy of management techniques to maximize the use of natural resources has provided an increase in corn grain yield (ZAGONEL; FERREIRA, 2013). Thus, plant density and row spacing are essential to optimize the exploitation of the environment, allowing adjusting the crop to the availability of solar radiation in the region and/or growing season (SANGOI; SILVA, 2006). Studies with modern cultivars have indicated a reduction in row spacing from 0.9 to $0.4-0.6 \mathrm{~m}$, and an increase in plant population from 60 to 75 thousand plants per hectare (GALVÃO et al., 2014). Silva et al. (2014) pointed out that plant populations between 60 and 80 thousand plants per hectare presented increases in yield of the order of 12.5 to $13.6 \%$.

The use of higher plant densities at smaller spacings allows a higher interception of photosynthetically active radiation, promoting higher grain yield (SANGOI et al., 2010). On the other hand, this strategy leads to lodging (KAPPES et al., 2011) and self-shading of plants, with a reduced yield, which can be overcome using plant regulators.

Plant growth regulators act on plant physiology, altering leaf architecture and reducing plant height to facilitate crop management, reduce the propensity to lodging, maximize the absorption of solar radiation, and increase yield (ZAGONEL; FERNANDES, 2007; ZAGONEL; FERREIRA, 2013; PRICINOTTO; ZUCARELI, 2014). Plant growth regulators such as paclobutrazol and trinexapac-ethyl (TE) has been studied in Brazil and abroad to the corn crop, but still without registration and recommendation of use (LEOLATO et al., 2017; KAMRAM et al., 2018).

Trinexapac-ethyl is a plant growth regulator that acts by inhibiting gibberellin biosynthesis, which is responsible for cell division and elongation. Studies with the wheat crop indicate that the use of TE changes leaf architecture of plants allowing a higher use of the incident radiation and, consequently, provides increases in yield (ZAGONEL; FERNANDES, 2007; PENCKOWSKI; FERNANDES, 2010). TE application on the corn crop changes plant morphology and minimizes the undesired effects caused by high densities, increasing yield due to an increment in plant population (ZAGONEL; FERREIRA, 2013; PRICINOTTO et al., 2015; MENDES
FAGHERAZZI et al., 2018).

This study aimed to evaluate the effects of plant populations associated with TE doses on the biometric characteristics of shoot and grain yield of corn cultivars with contrasting plant architecture.

\section{MATERIAL AND METHODS}

The experiments were conducted in the field during two agricultural seasons. In the first season (2010/2011), they were installed in Cambé-PR (23 $03^{\prime} 25^{\prime \prime} \mathrm{S}$ and $51^{\circ} 17^{\prime} 53^{\prime \prime} \mathrm{W}$, an altitude of $490 \mathrm{~m}$ ) and in the second season $(2011 / 2012)$ in Londrina-PR $\left(23^{\circ} 03^{\prime} 25^{\prime \prime} \mathrm{S}\right.$ and $51^{\circ} 17^{\prime} 53^{\prime \prime} \mathrm{W}$, an altitude of 490 $\mathrm{m})$. The data regarding the maximum and minimum air temperature, precipitation, and indication of phenological stages of corn throughout the experimental period are shown in Figure 1.

The soils of the experimental areas are classified as Eutroferric Red Latosol and Distroferric Red Latosol in Cambé-PR and Londrina-PR, respectively (SANTOS et al., 2013).

The experimental areas have been under notillage system, with soybean cultivation in the summer and wheat in the winter before the experiments were installed. Soil samples were collected in the areas at a depth of 0 to $0.20 \mathrm{~m}$ before experiment set up, presenting the following chemical characteristics: first season $-\mathrm{pH}_{\mathrm{CaCl} 2}=5.29 ; \mathrm{P}=9.07$ $\mathrm{mg} \mathrm{dm}{ }^{-3} ; \mathrm{K}^{+}=0.38 \mathrm{cmol}_{\mathrm{c}} \mathrm{dm}^{-3} ; \mathrm{Ca}^{2+}=5.93 \mathrm{cmol}_{\mathrm{c}}$ $\mathrm{dm}^{-3} ; \mathrm{Mg}^{2+}=1.57 \mathrm{cmol}_{\mathrm{c}} \mathrm{dm}^{-3} ; \mathrm{Al}^{3+}=0.00 \mathrm{cmol}_{\mathrm{c}}$ $\mathrm{dm}^{-3} ; \mathrm{H}^{+}+\mathrm{Al}^{3+}=4.09 \mathrm{cmol}_{\mathrm{c}} \mathrm{dm}^{-3} ; \mathrm{CEC}_{\text {effective }}=8.21$ $\mathrm{cmol}_{\mathrm{c}} \mathrm{dm}^{-3}$; base saturation $(\mathrm{V})=66.7 \%$; and organic matter $(\mathrm{OM})=26.16 \mathrm{~g} \mathrm{dm}^{-3}$; and second season $-\mathrm{pH}_{\mathrm{CaCl} 2}=5.26 ; \mathrm{P}=9.08 \mathrm{mg} \mathrm{dm}{ }^{-3} ; \mathrm{K}^{+}=$ $0.30 \mathrm{cmol}_{\mathrm{c}} \mathrm{dm}^{-3} ; \mathrm{Ca}^{2+}=4.28 \mathrm{cmol}_{\mathrm{c}} \mathrm{dm}^{-3} ; \mathrm{Mg}^{2+}=$ $1.05 \mathrm{cmol}_{\mathrm{c}} \mathrm{dm}^{-3} ; \mathrm{Al}^{3+}=0.00 \mathrm{cmol}_{\mathrm{c}} \mathrm{dm}^{-3} ; \mathrm{H}^{+}+\mathrm{Al}^{3+}=$ $3.37 \mathrm{cmol}_{\mathrm{c}} \mathrm{dm}^{-3} ; \mathrm{CEC}_{\text {effective }}=5.83 \mathrm{cmol}_{\mathrm{c}} \mathrm{dm}^{-3}$; base saturation $(\mathrm{V})=62.5 \%$; and organic matter $(\mathrm{OM})=$ $14.24 \mathrm{~g} \mathrm{dm}^{-3}$.

Two experiments were carried out at each season using corn cultivars with distinct leaf architecture (2B710 HX/flat and Status TL/erect). The experiments were installed in a randomized block design in a $5 \times 5$ factorial scheme, with four replications. Five plant populations $(40,60,80,100$, and 120 thousand plants $\left.\mathrm{ha}^{-1}\right)$ and five TE doses $(0$, 100, 200, 300, and $400 \mathrm{~g}$ a.i. ha ${ }^{-1}$ ) were studied. The commercial product Moddus $^{\circledR}$, which has a concentration of $250 \mathrm{~g}$ a.i. $\mathrm{L}^{-1}$, was used as a TE source. 

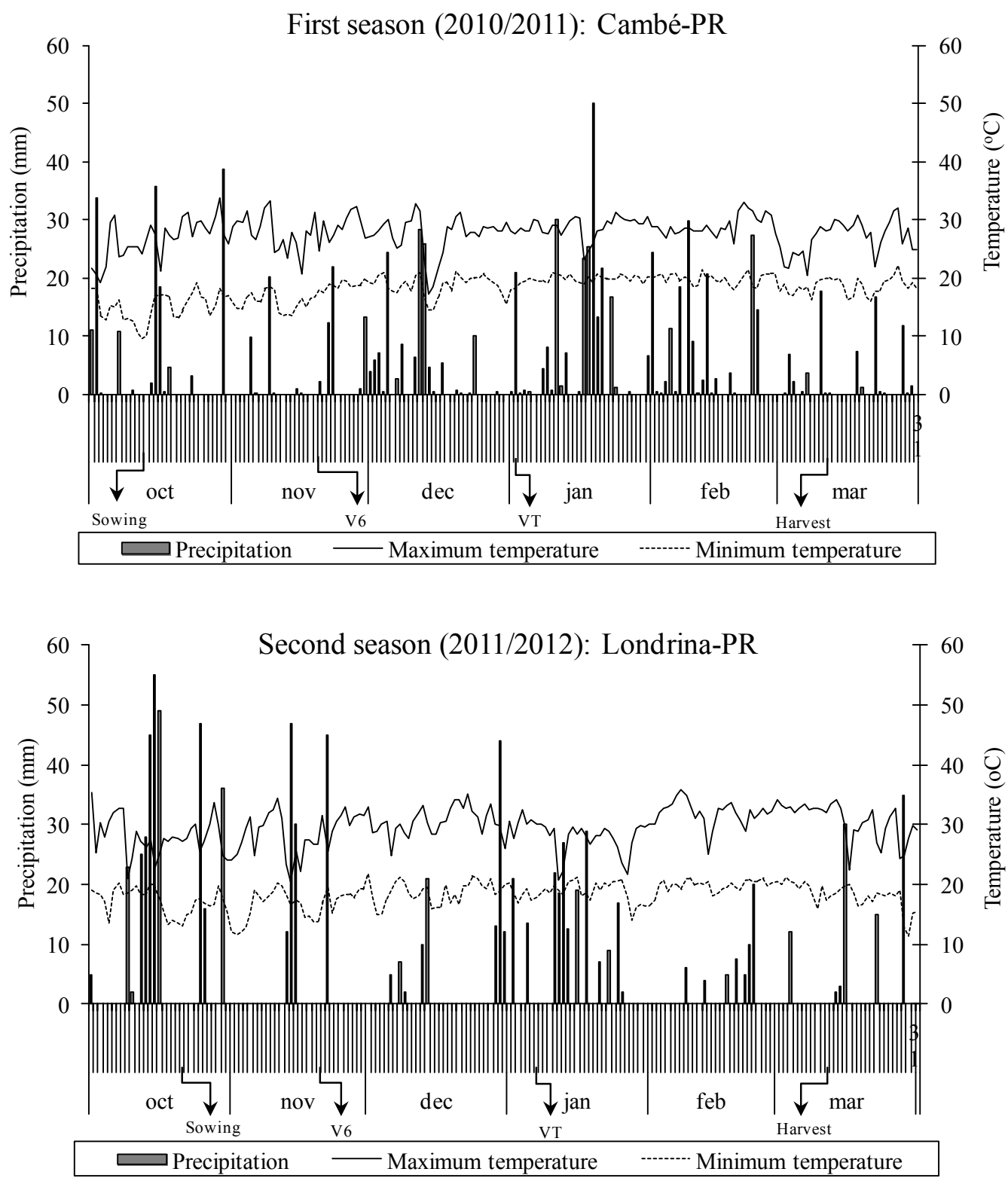

Figure 1. Values of maximum and minimum air temperature, precipitation, and the indication of phenological stages of corn in the first season (2010/2011) in Cambé, PR, and second season (2011/2012) in Londrina, PR.

The experimental plots consisted of six crop rows with $6.0 \mathrm{~m}$ in length and interrow spacing of $0.45 \mathrm{~m}$, considering as a useful area the four central rows with $5.0 \mathrm{~m}$ in length, totaling $9.0 \mathrm{~m}^{2}$.

Fertilization with nitrogen, phosphorus, and potassium at sowing was carried out with $300 \mathrm{~kg}$ $\mathrm{ha}^{-1}$ of the formulation 8-28-16 and followed the technical recommendations of Coelho (2006). Broadcast nitrogen fertilization was performed manually at the V4 stage (RITCHIE; HANWAY; BENSON, 2003) at a dose of $150 \mathrm{~kg} \mathrm{~N} \mathrm{ha}^{-1}$, using urea as the source.

The hybrid 2B710 HX has as characteristics an early cycle, flat leaf architecture, mean plant height of $200 \mathrm{~cm}$, mean ear insertion height of 110 $\mathrm{cm}$, yellow-orange grains, and low prolificacy. On the other hand, the hybrid Status TL has an early cycle, erect architecture, mean plant height of 240 $\mathrm{cm}$, mean ear insertion height of $117 \mathrm{~cm}$, orange grains, and high prolificacy.

Sowing was carried out with about 144 thousand seeds ha ${ }^{-1}$ on October 12, 2010, and October 19,2011 , for the first and second seasons, respectively. Plant densities were reached by manual thinning carried out at 20 days after sowing. Crop and phytosanitary management were those common to corn (EMBRAPA, 2011).

Trinexapac-ethyl was applied through foliar spraying at the V6 stage (RITCHIE; HANWAY; BENSON, 2003) using a pressurized knapsack sprayer $\left(\mathrm{CO}_{2}\right)$ equipped with air-induction twin fan spray tips, whose pressure and flow rate $\left(150 \mathrm{~L} \mathrm{ha}^{-1}\right)$ were constant.

Evaluations were performed after crop full 
flowering (VT) by taking ten plants per plot, with the purpose of evaluating plant height, ear insertion height, and stem diameter. Plant height was measured using a measuring tape considering the distance from soil to the leaf under the tassel. Similarly, ear insertion height was measured from soil to the ear base. Stem diameter was obtained with a caliper by measuring the internode between the second and third nodes above the soil level. The leaf area index was evaluated according to Francis, Rutger, and Palmer (1969). Grain yield was determined by harvesting the ears of the useful area of the plot; grains were threshed and weighed, and their weight was a corrected to a moisture content of $13 \%$ on a wet basis.

The data were submitted to analysis of variance, being tested by the contrast of interest and practical importance previously established by the Ftest at $5 \%$ probability, and to the quadratic polynomial regression analysis. The means of each treatment were adjusted considering plant populations and $\mathrm{TE}$ doses as independent variables, being tested the coefficients of regression models adjusted by the Student t-test at $5 \%$ probability. The response surfaces were constructed using the software Statistica $12^{\circledR}$.

\section{RESULTS AND DISCUSSION}

The summary of the Student t-test for the tested model and the significance of parameters are shown in Table 1. We considered that there was an interaction among the factors when the crossed terms of the model were significant.

Table 1. Student t-test and significance of coefficients of the model tested for plant height ( $\mathrm{PH})$, ear insertion height (EH), stem diameter (SD), leaf area index (LAI), and grain yield (GY) of corn hybrids (2B710 HX and Status TL) in response to plant populations and doses of trinexapac-ethyl in the 2010/2011 and 2011/2012 seasons.

\begin{tabular}{|c|c|c|c|c|c|}
\hline \multirow{3}{*}{ Parameter } & $\mathrm{PH}$ & EH & $\mathrm{SD}$ & LAI & GY \\
\hline & \multicolumn{5}{|c|}{ t-value } \\
\hline & \multicolumn{5}{|c|}{ 2B710 HX - 2010/2011 } \\
\hline Intercept & $60.42 * * *$ & $33.87 * * *$ & $30.12 * * *$ & $-2.74 * *$ & $8.32 * * *$ \\
\hline Population & $6.05 * * *$ & $6.27 * * *$ & $-4.41 * * *$ & $16.67 * * *$ & $16.04 * * *$ \\
\hline Population $^{2}$ & $-4.15 * * *$ & $-4.23 * * *$ & $2.49 *$ & $-11.28 * * *$ & $-14.17 * * *$ \\
\hline Dose & $2.08 *$ & $1.99 *$ & $1.91 *$ & $-0.43^{\mathrm{ns}}$ & $2.68 * *$ \\
\hline $\operatorname{Dose}^{2}$ & $-5.12 * * *$ & $-4.17 * * *$ & $-0.76^{\mathrm{ns}}$ & $-0.65^{\mathrm{ns}}$ & $-4.07 * * *$ \\
\hline \multirow[t]{2}{*}{ Population $\times$ dose } & $-3.59 * * *$ & $-3.07 * *$ & $-2.34 *$ & $1.00^{\mathrm{ns}}$ & $-0.04^{\mathrm{ns}}$ \\
\hline & \multicolumn{5}{|c|}{ 2B710 HX - 2011/2012 } \\
\hline Intercept & $25.05 * * *$ & $16.38 * * *$ & $36.35 * * *$ & $10.18^{* * *}$ & $8.49 * * *$ \\
\hline Population & $2.62 *$ & $1.5^{*}$ & $-5.59 * * *$ & $46.78^{* * *}$ & $12.60 * * *$ \\
\hline Population $^{2}$ & $-1.95^{\mathrm{ns}}$ & $-0.39^{\mathrm{ns}}$ & $2.97 * *$ & $-3.35^{\mathrm{ns}}$ & $-11.95 * * *$ \\
\hline Dose & $-0.34^{*}$ & $1.1^{*}$ & $2.03^{\mathrm{ns}}$ & $3.72 * * *$ & $1.36^{\mathrm{ns}}$ \\
\hline $\operatorname{Dose}^{2}$ & $-1.04^{\mathrm{ns}}$ & $-3.04^{\mathrm{ns}}$ & $-1.09^{\mathrm{ns}}$ & $-2.41^{\mathrm{ns}}$ & $-2.56^{*}$ \\
\hline \multirow[t]{2}{*}{ Population $\times$ dose } & $-1.46^{\mathrm{ns}}$ & $-1.96^{\mathrm{ns}}$ & $-2.08^{\mathrm{ns}}$ & $0.86^{\mathrm{ns}}$ & $-0.03^{\mathrm{ns}}$ \\
\hline & \multicolumn{5}{|c|}{ Status TL $-2010 / 2011$} \\
\hline Intercept & $80.25 * * *$ & $53.47 * * *$ & $44.38 * * *$ & $5.23 * * *$ & $38.72 * * *$ \\
\hline Population & $10.16^{* * *}$ & $10.85 * * *$ & $-8.14^{* * *}$ & $8.61 * * *$ & $9.43 * * *$ \\
\hline Population $^{2}$ & $-10.39 * * *$ & $-9.84 * * *$ & $4.33 * * *$ & $-3.05^{* *}$ & $-9.28 * * *$ \\
\hline Dose & $-8.14 * * *$ & $-9.35 * * *$ & $-1.70^{\mathrm{ns}}$ & $-2.06^{\mathrm{ns}}$ & $3.06^{* *}$ \\
\hline $\operatorname{Dose}^{2}$ & $-3.56^{\mathrm{ns}}$ & $-2.03^{\mathrm{ns}}$ & $1.95^{\mathrm{ns}}$ & $1.94^{\mathrm{ns}}$ & $-6.10 * * *$ \\
\hline \multirow[t]{2}{*}{ Population $\times$ dose } & $0.76^{\mathrm{ns}}$ & $0.60^{\mathrm{ns}}$ & $0.06^{\mathrm{ns}}$ & $1.59^{\mathrm{ns}}$ & $3.62 * * *$ \\
\hline & \multicolumn{5}{|c|}{ Status TL $-2011 / 2012$} \\
\hline Intercept & $25.95 * * *$ & $21.32 * * *$ & $29.72 * * *$ & $2.87 * *$ & $34.54 * * *$ \\
\hline Population & $1.79^{\mathrm{ns}}$ & $2.40^{\mathrm{ns}}$ & $-5.56^{* * *}$ & $5.11 * * *$ & $3.96^{* * *}$ \\
\hline Population $^{2}$ & $-1.93^{\mathrm{ns}}$ & $-2.27^{\mathrm{ns}}$ & $2.97 * *$ & $-0.74^{\mathrm{ns}}$ & $-2.62 *$ \\
\hline Dose & $-1.30^{\mathrm{ns}}$ & $-1.35^{\mathrm{ns}}$ & $-1.91^{\mathrm{ns}}$ & $-0.94^{\mathrm{ns}}$ & $10.66^{* * *}$ \\
\hline $\operatorname{Dose}^{2}$ & $3.50^{\mathrm{ns}}$ & $2.04^{\mathrm{ns}}$ & $1.91^{\mathrm{ns}}$ & $0.28^{\mathrm{ns}}$ & $-11.39 * * *$ \\
\hline Population $\times$ dose & $-3.04^{\mathrm{ns}}$ & $-2.49^{\mathrm{ns}}$ & $0.20^{\mathrm{ns}}$ & $1.29^{\mathrm{ns}}$ & $-5.15 * * *$ \\
\hline
\end{tabular}

$*, * *$,and $* * *$ : significant at 5,1 , and $0.1 \%$ significance, respectively; ${ }^{\text {ns }}$ : not significant. 
In both seasons of the hybrid 2B710 HX, an increase in plant population increased plant height and ear insertion height at all TE doses (Figure 2). In the first season, the highest plant height $(258.6 \mathrm{~cm})$ and ear insertion height $(144.7 \mathrm{~cm})$ were observed with the association of the highest plant population (120 thousand plants $\mathrm{ha}^{-1}$ ) with the absence of the plant growth regulator (Figure $2 \mathrm{~A}$ and $\mathrm{C}$ ). In both seasons, the use of TE reduced plant height and ear insertion height in all populations, and the reduction

\section{(A) 2B710 HX-First sea son}

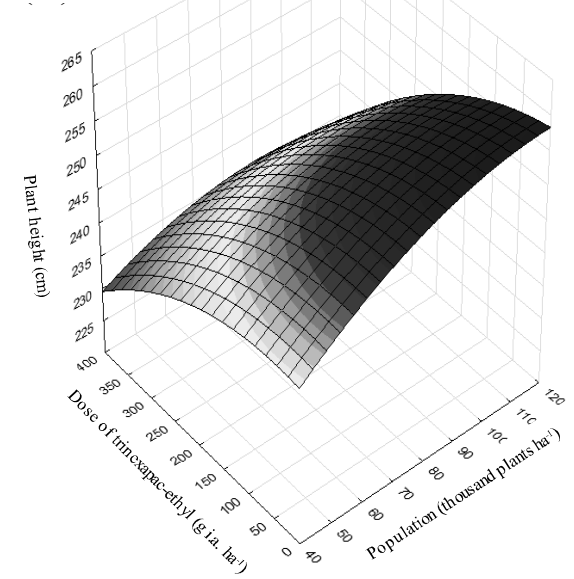

$\mathrm{Y}=224.65+0.5593^{*} \mathrm{P}+0.0248 * \mathrm{TE}-0.0023^{*} \mathrm{P}^{2}-0.1147 \mathrm{e}^{-3 *} \mathrm{TE}^{2}-0.3361 \mathrm{e}^{3 *}(\mathrm{P} * \mathrm{TE}) \quad \mathrm{R}^{2}=0.83$

(C) $2 \mathrm{~B} 710 \mathrm{HX}-1^{\mathrm{a}}$ First sea son

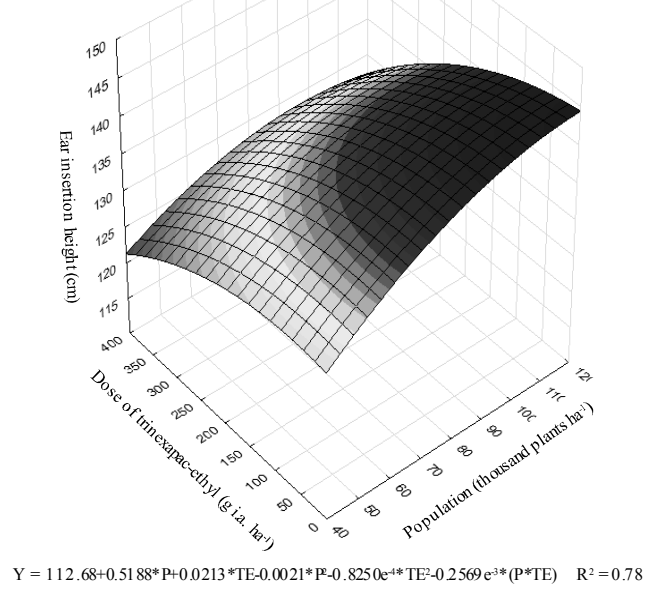

was higher as TE doses increased (Figure 2). In the first season, the maximum plant height and ear insertion height were observed in plant populations lower than 120,000 plants ha ${ }^{-1}$ as TE doses increased (Figure $2 \mathrm{~A}$ and $\mathrm{C}$ ). Thus, the highest plant height $(235.8 \mathrm{~cm})$ and ear insertion height $(128.6 \mathrm{~cm})$ were observed in populations of 92.4 and 99.0 thousand plants $\mathrm{ha}^{-1}$, respectively, when the highest TE dose (400 $\mathrm{g} \mathrm{ha}^{-1}$ ) was used (Figure 2A and C).

\section{(B) 2B710 HX - Second sea son}

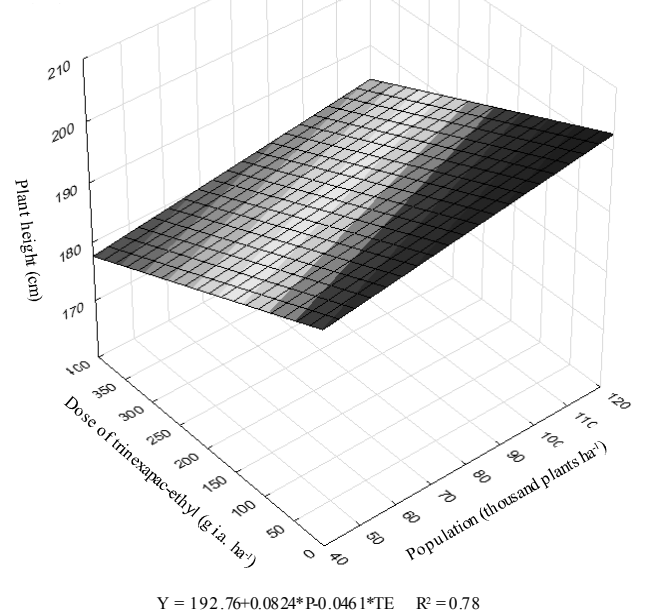

(D) $2 \mathrm{~B} 710 \mathrm{HX}$ - Second sea son

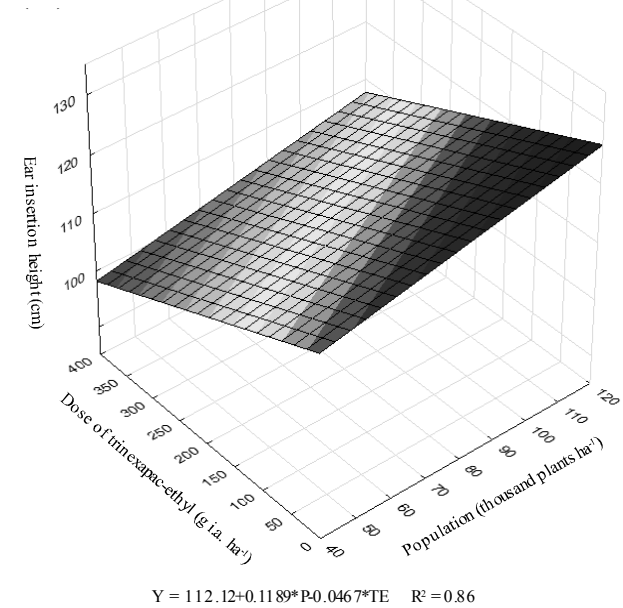

Figure 2. Plant height (A and $B$ ) and ear insertion height $(C$ and $D)$ of the corn hybrid $2 B 710 \mathrm{HX}$ in the first $(A$ and $C)$ and second season (B and $\mathrm{D}$ ) in response to plant populations and doses of trinexapac-ethyl.

Still in the first season, reductions in plant height and ear insertion height in the hybrid 2B710 HX provided with an increase in TE doses were more pronounced in the highest plant populations $\left(120,000\right.$ plants ha $\left.{ }^{-1}\right)$, which was about 77 and $93 \%$ higher, respectively, when compared to reductions in the lowest population $\left(40,000\right.$ plants $\left.\mathrm{ha}^{-1}\right)$. A high number of plants per area increases the intraspecific competition by light, which provides a higher stem growth (SANGOI et al., 2002).
Based on the population of 65,000 plants $\mathrm{ha}^{-1}$, the commercially recommended population for the cultivar, a plant height of $251.3 \mathrm{~cm}$ and ear insertion height of $137.5 \mathrm{~cm}$ were observed in the absence of TE, while reductions with the highest TE dose $\left(400 \mathrm{~g} \mathrm{ha}^{-1}\right)$ reached 17.2 and $11.4 \mathrm{~cm}$, respectively (Figure $2 \mathrm{~A}$ and $\mathrm{C}$ ). The association of TE doses equal to or higher than $250 \mathrm{~g} \mathrm{ha}^{-1}$ with plant populations above the recommended values provided lower heights when compared to those 
observed in the population of 65 thousand plants $\mathrm{ha}^{-1}$ with the absence of TE.

The hybrid 2B710 HX grown in the second season showed a similar response for plant height and ear insertion height in relation to the increment of plant population since the highest heights were observed with the highest population (120 thousand plants $\mathrm{ha}^{-1}$ ) in the absence of TE (Figure 2B and D). However, no interaction was observed between the factors studied in the second season (Table 1), and the increase in plant population provided a linear increase in plant height and ear insertion height, as well as TE reduced these variables as the used dose increased (Figure 2B and D).

In the second season, plant height and ear insertion height were reduced by 18.5 and $18.7 \mathrm{~cm}$, respectively, when plants were submitted to the highest TE dose $\left(400 \mathrm{~g} \mathrm{ha}^{-1}\right)$ when compared to the

(A)

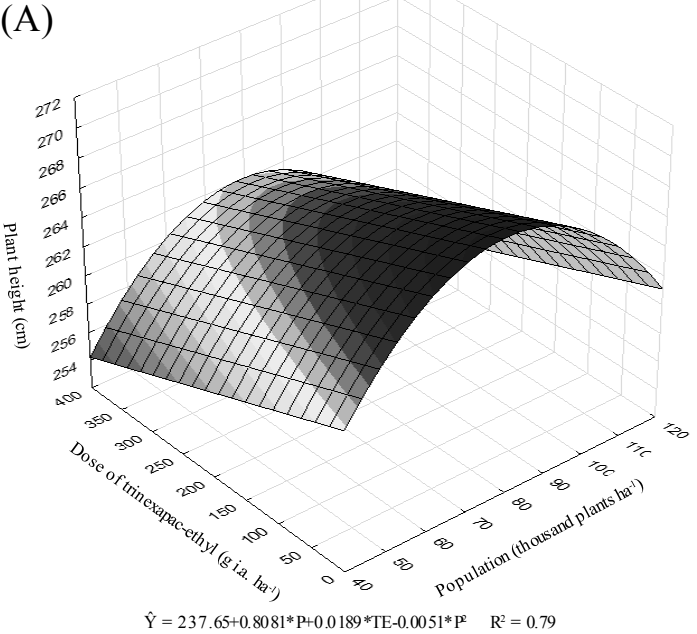

recommended population of 65,000 plants $\mathrm{ha}^{-1}$ (Figure 2B and D). All plant populations, when submitted to TE doses higher than $150 \mathrm{~g} \mathrm{ha}^{-1}$, showed lower heights than that observed with 65 thousand plants ha ${ }^{-1}$ in the absence of TE (Figure 2B and D).

For the hybrid Status TL grown in the first season, no interaction was observed between the studied factors on the variables plant height and ear insertion height (Table 1). The highest plant height and ear insertion height were observed in the absence of TE, in which the points of the maximum height of 269.6 and $169.35 \mathrm{~cm}$ were observed with populations of 79.2 and 90.2 thousand plants ha $^{-1}$, respectively. Increased TE reduced plant height and ear insertion height (Figure 3), in which the highest reductions $(7.56$ and $7.44 \mathrm{~cm})$ were observed at the highest dose $\left(400 \mathrm{~g} \mathrm{ha}^{-1}\right)$.

(B)

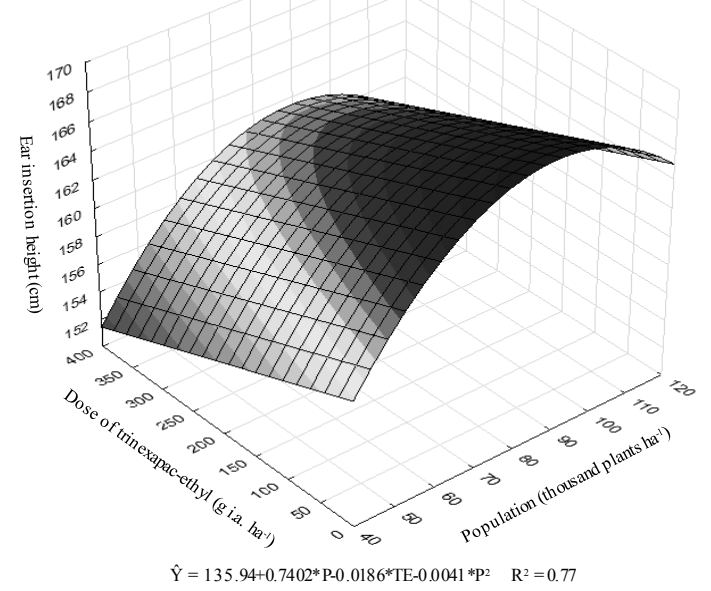

Figure 3. Plant height (A) and ear insertion height (B) of the corn hybrid State TL in the first season in response to plant populations and doses of trinexapac-ethyl.

Plant height (mean of $188.4 \mathrm{~cm}$ ) and ear insertion height (mean of $128.3 \mathrm{~cm}$ ) of the hybrid Status TL grown in the second season showed no responses to the studied factors (Table 1). The precipitation from November 23 to December 28, 2011, represented a sum of $46.2 \mathrm{~mm}$ (Figure 1), thus below that necessary for an adequate corn development, which was of $210 \mathrm{~mm}$ in this period (RADIN et al., 2003). Because this period coincided with the crop development stages (V7 to V15), in which stem growth and elongation are intense, this stress may have restricted the vegetative growth of corn, not providing conditions for the effects of the increase in plant population and $\mathrm{TE}$ doses to be observed. The absence of effects of TE on the heights of the hybrid Status TL was also observed by Zagonel and Ferreira (2013), but without association with water deficit.

Trinexapac-ethyl acts by inhibiting the $3 \beta$ hydroxylase enzyme at the end of the gibberellic acid synthesis pathway, drastically reducing the level of active gibberellic acid $\left(\mathrm{GA}_{1}\right)$, increasing its low- activity precursor $\left(\mathrm{GA}_{20}\right)$ (DAVIES, 2010). Thus, because TE acts by inhibiting the gibberellin synthesis, plants submitted to the plant growth regulator in the V6 stage have a significant reduction in cell division and elongation in a period considered as of a high increase in stem elongation (RITCHIE; HANWAY; BENSON, 2003), reducing their height. Lower plant height and ear insertion height provide plants with a center of gravity closer to the ground, which reduces the predisposition of corn to lodging (SANGOI et al., 2001).

Zagonel and Ferreira (2013) worked with the hybrid Status TL and TE applications at doses of 0.0, $187.5,375$, and $562.5 \mathrm{~g} \mathrm{ha}^{-1}$ at different development stages (V2, V4, V6, and V8) and did not observe a reduction in plant height with the use of this plant growth regulator. The divergence of results in relation to this study is possibly associated with the interaction between genotype, environment, and crop management. Reduction in plant height with the use of TE was also observed in wheat (CONTRERAS et al., 2012), rice (ARF et al., 2012), 
and soybean (LINZMEYER JUNIOR et al., 2008).

A reduction in stem diameter of corn plants was observed as the population increased, regardless of the hybrid and season (Figure 4). The higher competition of plants for light leads to intense stem elongation, directing photoassimilates for vertical growth rather than development in thickness (SANGOI et al., 2002). The reduction in stem diameter by increasing plant population may have undesirable consequences, such as an increased occurrence of lodging and stem collapse (KAPPES et al., 2011). Stem not only acts as a support structure for leaves and inflorescences but also as a storage structure of soluble solids that will be used in grain formation. Thus, the thinner the stem diameter is, the lower the capacity to store photoassimilates to be translocated to the grains.

For the hybrid 2B710 HX in the first season, stem diameter showed an interaction between plant populations and TE doses (Table 1). TE increased

(A) 2B710 HX-First sea son

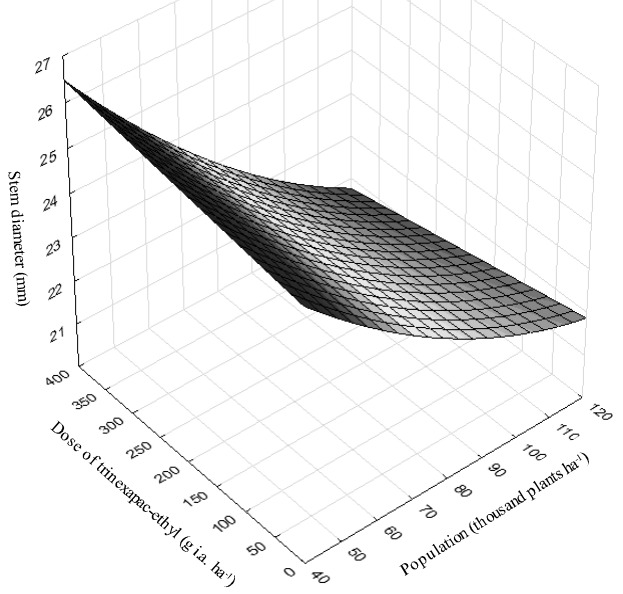

$\mathrm{Y}=29.410-0.1067 * \mathrm{P}+0.0042^{*} \mathrm{TE}+0.3656 \mathrm{e}^{3 *} \mathrm{P}^{2}-0.5824 \mathrm{e}^{4 *}(\mathrm{P} * \mathrm{TE}) \quad \mathrm{R}^{2}=0.86$

(C) Status TL-First season

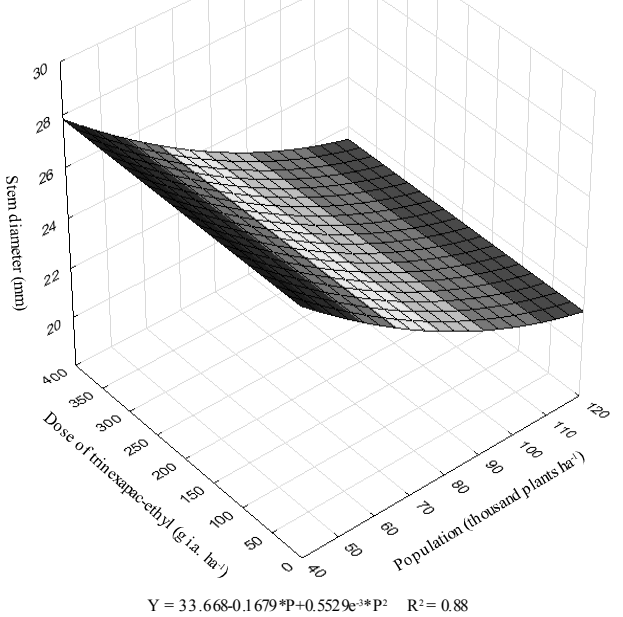

the stem diameter of corn plants under populations below 72.2 thousand plants ha ${ }^{-1}$ (Figure 4A and B). From this plant population, TE reduced stem diameter as population and TE doses increased.

Souza et al. (2013) also observed an increase in stem diameter of soybean plants with the use of TE and attributed this result to the fact that photoassimilates were deviated from the destination of increasing plant height and thus stem diameter, which may also have occurred with corn plants in populations below 72.2 thousand plants $\mathrm{ha}^{-1}$. In higher populations, the effect of intraspecific competition generated by the increased population was possibly highlighted in relation to the ability of $\mathrm{TE}$ to reduce growth. Leolato et al. (2017) also observed a reduction in plant height and an increase in stem diameter of the corn hybrid P30F53YH with the use of TE at a dose of $150 \mathrm{~g} \mathrm{ha}^{-1}$ in an experiment carried out in Lages-SC.

\section{(B) 2B710 HX-Second sea son}

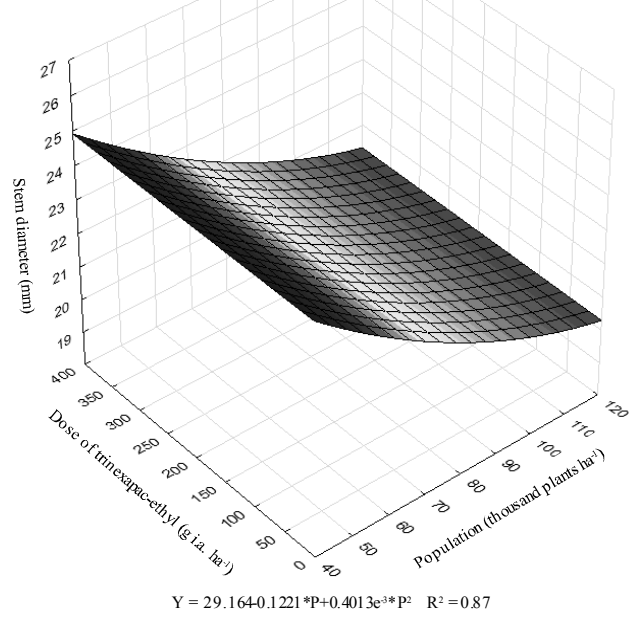

(D) Status TL - Second sea son

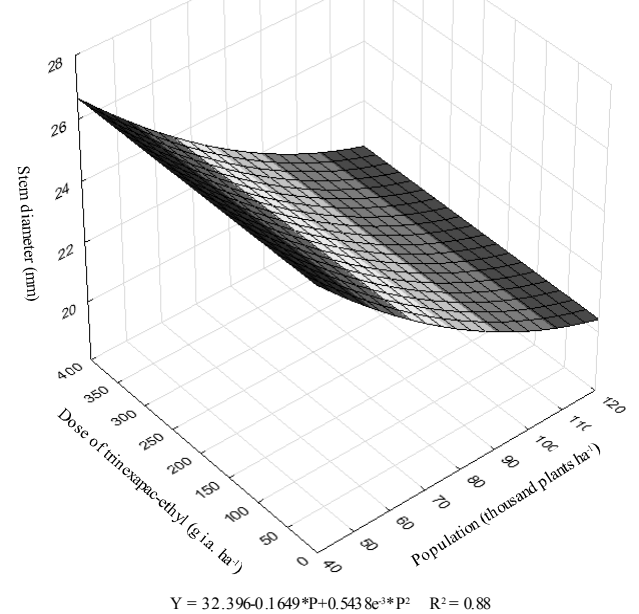

Figure 4. Stem diameter of the corn hybrids 2B710 HX (A and B) and Status TL (C and D) in the first (A and C) and second seasons (B and $\mathrm{D})$, respectively, in response to plant populations and doses of trinexapac-ethyl. 
For both hybrids and seasons, linear increases in the leaf area index were observed in response to an increase of plant population (Figure 5). Because leaf area index is given by the relationship between the leaf area of plants and the area of soil occupied by them, it is expected that an increase in the number of plants per hectare leads to an increase in the leaf area index of the crop.

Leaf area index was affected by the use of TE
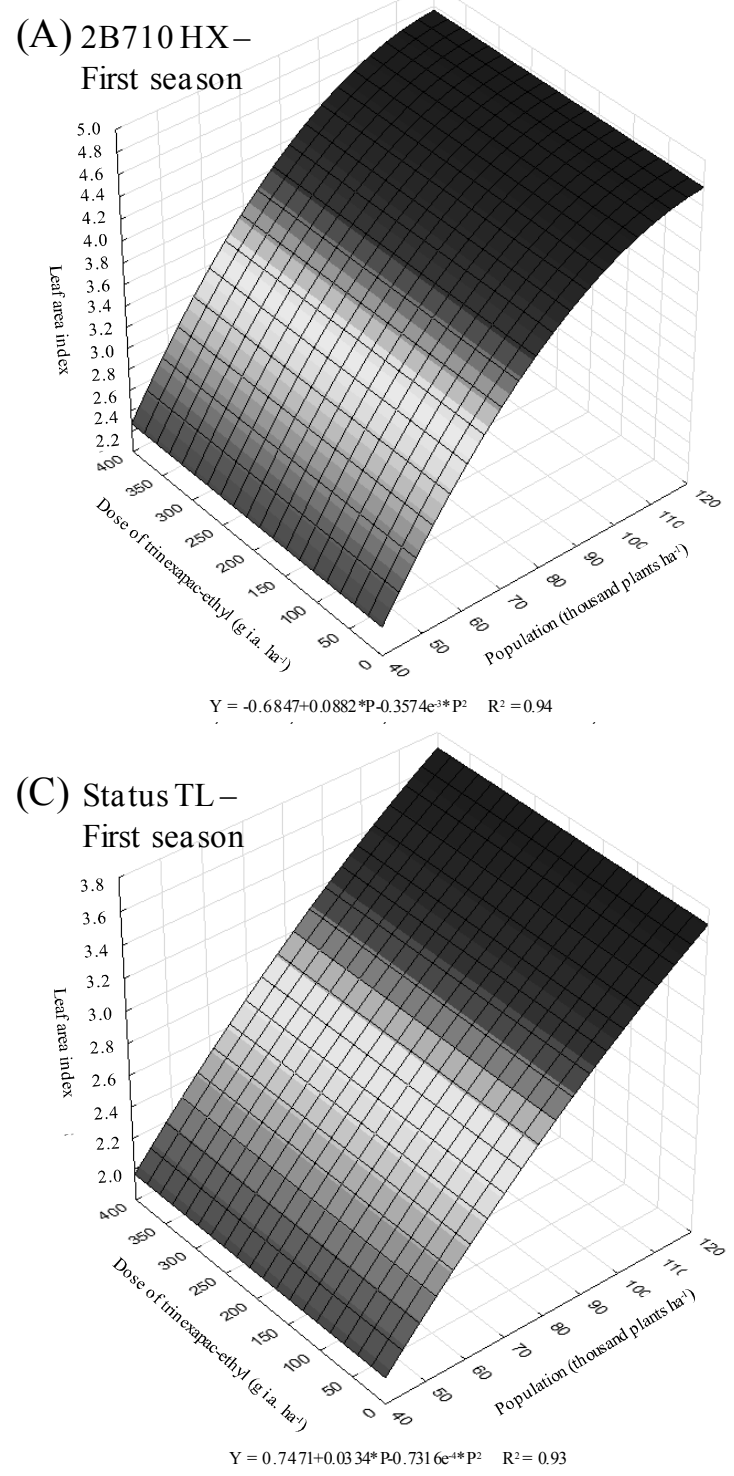

Figure 5. Leaf area index of the corn hybrids 2B710 HX (A and B) and Status TL (C and D) in the first (A and C) and second seasons (B and $\mathrm{D}$ ), respectively, in response to plant populations and doses of trinexapac-ethyl.

The response of grain yield of the hybrid 2B710 HX to the studied factors was similar in both seasons, with effects of plant populations and TE doses, but without interaction between them (Table 1 , Figure $6 \mathrm{~A}$ and $\mathrm{B})$. The increased plant population led to an increase in yield grains with the highest yields, which were $11,857.70$ and $11,712.50 \mathrm{~kg} \mathrm{ha}^{-1}$ for populations of 93.40 and 87.10 thousand plants $\mathrm{ha}^{-1}$ in the first and second seasons, respectively (Figure 6). The maximum yields verified in the only in the hybrid 2B710 HX in the second season, showing an increase in its values as TE doses increased (Table 1, Figure 5B). Zagonel and Ferreira (2013) verified that the use of TE provided a decrease in length and increase in width of corn leaves located just above the ear. Thus, the increase in leaf width observed in the present study is probably due to the use of TE, promoting an increase in the leaf area index.

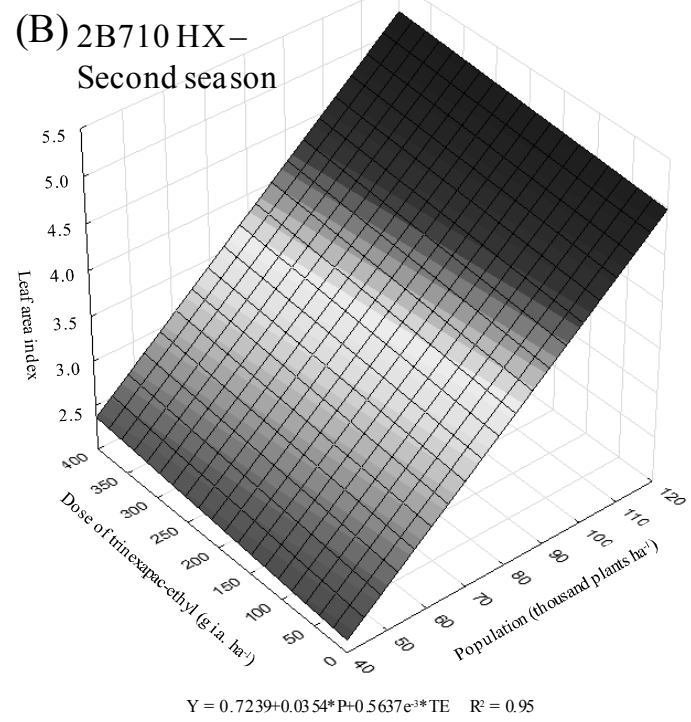

(D) Status TL-

Second season

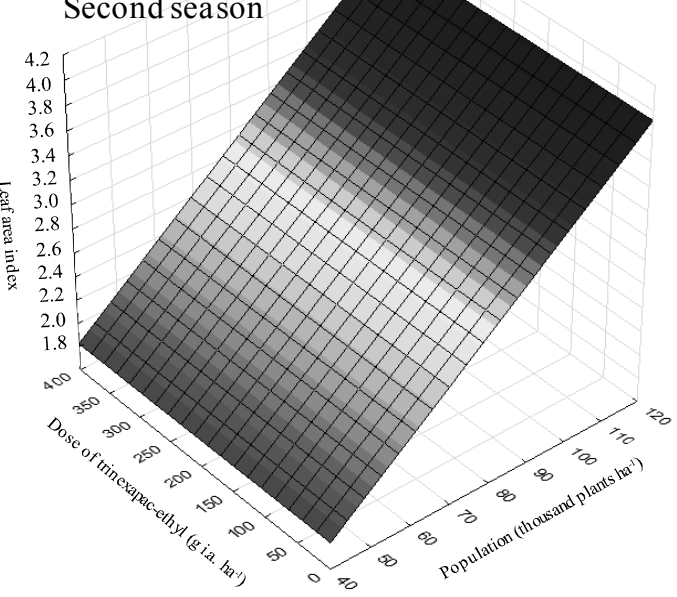

$\mathrm{Y}=0.7766+0.0262 * \mathrm{P} \quad \mathrm{R}^{2}=0.95$ absence of the plant growth regulator were higher than those obtained using the commercially recommended plant population for the hybrid $(65$ thousand plants ha $\left.{ }^{-1}\right)$ in both seasons $(11,099.20$ and $\left.11,255.40 \mathrm{~kg} \mathrm{ha}{ }^{-1}\right)$. It shows that favorable edaphoclimatic conditions and appropriate cultivation practices allow the use of higher plant populations, with an increased yield. The behavior of grain yield in response to an increase in plant population is in accordance with the results of other 
studies in this area (SANGOI et al., 2010; KAPPES et al., 2011; SANGOI et al., 2013).

In the first season, the use of the plant growth bioregulator favored grain yield of the hybrid 2B710 $\mathrm{HX}$, with a maximum increase of $329.70 \mathrm{~kg} \mathrm{ha}^{-1}$ at a dose of $176 \mathrm{~g} \mathrm{ha}^{-1}$, regardless of the associated plant population (Figure 6A). Morphological changes caused by the use of TE, such as lower plant height, probably favored the use of incident solar radiation, optimizing photoassimilate production, which leads to an increase in grain yield. Morphological changes of plants with TE favoring the increase in yield have also been reported in wheat and rice (ESPINDULA et al., 2009; ESPINDULA et al., 2011; ARF et al.,

(A) 2B710 HX-First sea son

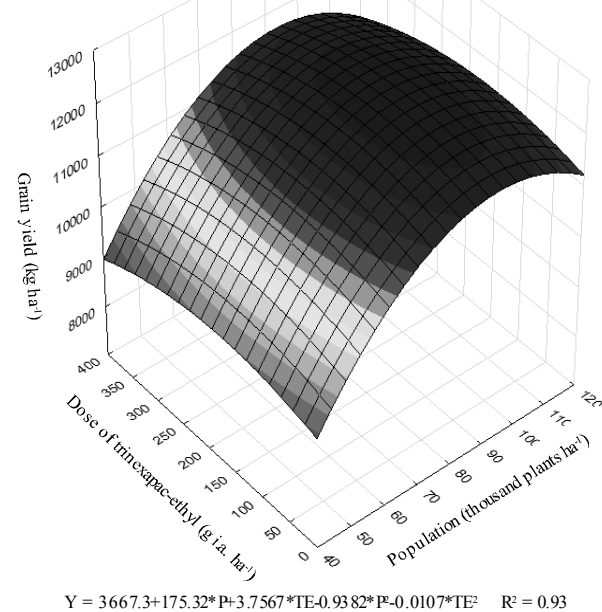

(C) Status TL-First season

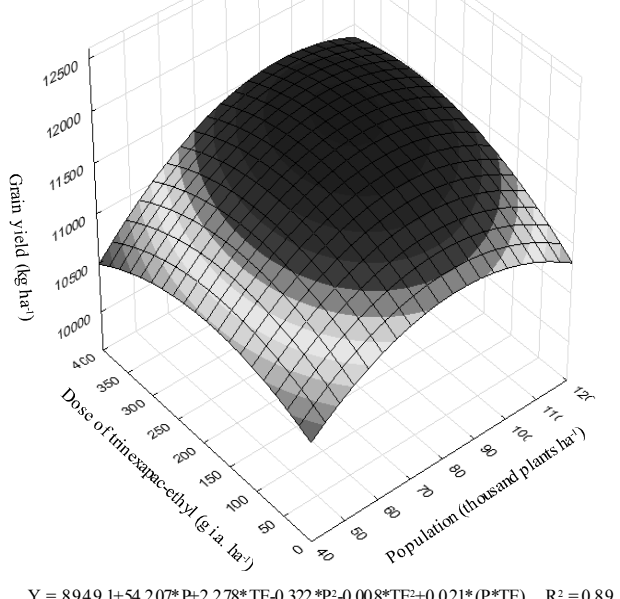

2012).

However, in the second season, TE application was detrimental to the crop, with a reduction in grain yield reaching $448 \mathrm{~kg} \mathrm{ha}^{-1}$ with its highest dose (Figure 6B). Contreras et al. (2012) and Alvarez, Crusciol, and Nascente (2014) also verified a reduction in grain yield in wheat and rice with the use of TE. The difference in response of the hybrid in both seasons was due to the interaction between the studied factors and edaphoclimatic factors present at each cultivation. Penckowski and Fernandes (2010) observed that the response of wheat to the use of ET was directly related to soil texture, fertility, and meteorological conditions.

(B) 2B710 HX-Second season

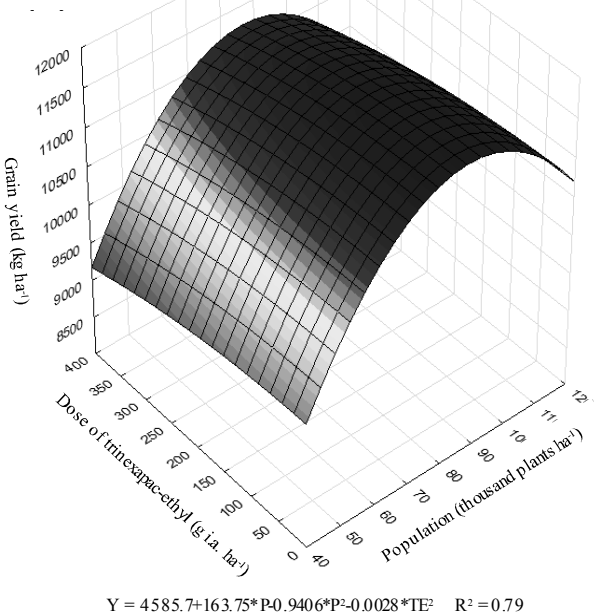

(D) Status TL - Second season

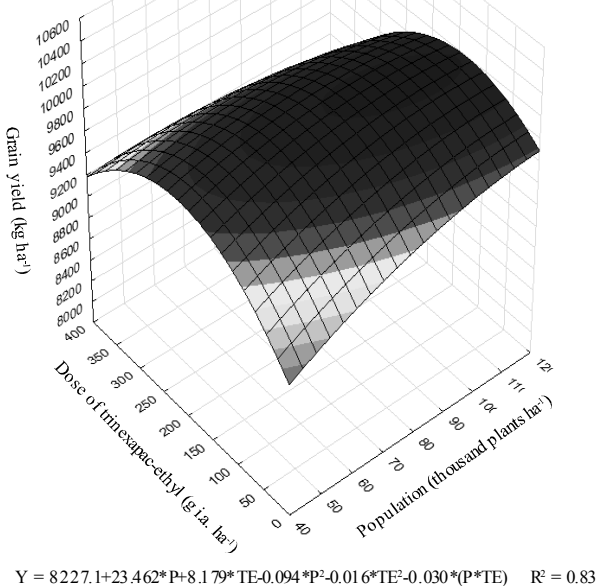

Figure 6. Grain yield of the corn hybrids 2B710 HX (A and B) and Status TL (C and D) in the first (A and C) and second seasons $(\mathrm{B}$ and $\mathrm{D})$, respectively, in response to plant populations and doses of trinexapac-ethyl.

In the second season, an increase in the leaf area index was observed in corn plants of the hybrid 2B710 HX due to the use of TE (Table 1). The largest leaf area, coupled with the precipitation restriction occurred in the second season from January 29 to February 27 (Figure 1), may have worsened losses caused by water deficit due to the higher plant transpiration related to a higher leaf area. Radin et al. (2003) estimated that the demand for water by the corn crop in this period (R3 and R4 stages) is approximately $150 \mathrm{~mm}$, being recorded in this 30 -day interval only $10.1 \mathrm{~mm}$. The lack of water

Rev. Caatinga, Mossoró, v. 32, n. 3, p. 667 - 678, jul. - set., 2019 
available to plants during this period coincided with the grain filling stage, in which cell division and expansion and starch accumulation in corn grains occur with higher intensity, thus compromising grain development and hybrid response to TE.

Significant interactions between the studied factors were observed in both seasons for grain yield of the hybrid Status TL (Table 1). Quadratic responses of yield were obtained with an increase in plant population at different TE doses (Figure 6C and $\mathrm{D})$. Based on the absence of TE in the first season, the maximum yield $\left(11,224.80 \mathrm{~kg} \mathrm{ha}^{-1}\right)$ was obtained with a population of 84.00 thousand plants $\mathrm{ha}^{-1}$ (Figure 6C). Yield response to an increase in plant population corroborates the results obtained for the hybrid 2B710 $\mathrm{HX}$, as well as other studies (SANGOI et al., 2010; KAPPES et al., 2011; SANGOI et al., 2013). In the second season, the highest yield $\left(9,688.90 \mathrm{~kg} \mathrm{ha}^{-1}\right)$ was obtained with a population of 120 thousand plants $\mathrm{ha}^{-1}$ in the absence of TE and, therefore, the maximum yield point (critical point) was not reached with the studied populations (Figure 6D).

In both seasons, the population responsible for the maximum grain yield of the hybrid Status TL was higher than the commercially recommended population $\left(70,000\right.$ plants $\left.\mathrm{ha}^{-1}\right)$. These results showed that the interaction between genotype and environment in both seasons presented favorable conditions to grain yield in high plant populations.

With the significant interaction between factors, the plant population related to the maximum grain yield (critical point) was changed. In the first season, the maximum yield of the hybrid Status TL was reached with a population of 92.20 thousand plants $\mathrm{ha}^{-1}$ and a TE dose of $251.00 \mathrm{~g} \mathrm{ha}^{-1}$, which corresponded to $11,731.60 \mathrm{~kg} \mathrm{ha}^{-1}$. This new critical point provided a yield of $506 \mathrm{~kg} \mathrm{ha}^{-1}$ more than the maximum yield in the absence of the plant growth regulator (84 thousand plants ha ${ }^{-1}$ ) (Figure 6C). The lower plant height provided by TE possibly changed plant morphology, reducing the self-shading caused by higher populations, favoring grain production per plant even in populations above that considered ideal.

In the second season, from increments provided by the use of TE, plant population related to the maximum yield was obtained in 99.00 thousand plants $\mathrm{ha}^{-1}$ associated with a TE dose of $157.50 \mathrm{~g} \mathrm{ha}^{-1}$, providing a grains yield of $10,032.10$ $\mathrm{kg} \mathrm{ha}^{-1}$, i.e., $343.20 \mathrm{~kg} \mathrm{ha}^{-1}$ more than that obtained in the absence of TE (Figure 6D).

Zagonel and Ferreira (2013) observed no effects of doses and application times of TE on the same hybrid, but the interaction between factors and the environment did not provide conditions for changes in the morphological characteristics of plants and/or crop production components. These authors also observed that corn response to the use of $\mathrm{TE}$ is not frequent and varies according to climate factors, cultivars, doses, and application times.

Similarly, Leolato et al. (2017) observed no effects of TE on grain yield of the hybrid P30F53YH even with a reduction in plant size and an increase in stem diameter. They affirmed that the reduction in the distance of internodes above the ear might have increased self-shading of upper leaves, restricting the interception of solar radiation. In addition, the smaller size of internodes might have reduced the amount of reserves mobilized for grain filling, which eventually resulted in a reduction of the one thousand-grain weight in the experiment.

One of the ways to maximize the interception of solar radiation, and thus, the grain yield is by increasing the leaf area index (SANGOI et al., 2013). In this study, no effects of TE were observed on this characteristic, except for the hybrid 2B710 HX in the second season. However, Argenta, Silva, and Sangoi (2001) stated that not only the leaf area but also the angle of insertion and distribution of leaves in the plant and the characteristics of light absorption by leaf are components influencing the interception of solar radiation.

Kasele et al. (1994) identified a higher photosynthetic activity in smaller corn leaves when compared to those larger. This higher activity is due to an increase in stomatal density, protein and chlorophyll contents, and, consequently, $\mathrm{CO}_{2}$ assimilation rate. Therefore, TE possibly altered leaf architecture of plants, such as smaller and erect leaves, reducing the self-shading and increasing photosynthesis (ESPINDULA et al., 2009).

The effects of plant population and TE doses were more beneficial to the cultivation in the first season due to better precipitation conditions (Figure 1 ), which favored crop development and yield. The use of TE is not indicated in the wheat crop in case of water deficiency during crop development (RCBPTT, 2017).

Because the use of ET restricts plant height and leaf area index, it may reduce the individual production of corn plants, but this reduction can be compensated by the use of higher plant populations, resulting in higher grain yield per area. The best results on the use of TE was expected to be observed in the hybrid 2B710 HX due to its characteristics of flat leaf architecture, which promotes a higher crop self-shading. However, despite the positive effect of $\mathrm{TE}$ on grain yield of the hybrid $2 \mathrm{~B} 710 \mathrm{HX}$ in the first seasons, the hybrid Status TL showed higher gains yield in both seasons. These results show that even hybrids with leaf architecture favorable to the use of high plant populations may have their productive potential increased with the use of TE.

The use of TE is a promising technique for corn management, with the potential for increasing yield. However, the use of this plant growth regulator is simple because factors inherent to crop, such as cultivar, soil fertility, plant nutrition, climate conditions are essential to obtain positive results. 


\section{CONCLUSIONS}

The increase in plant population increases plant height, ear insertion height, and leaf area index, besides reducing the stem diameter of corn plants.

The use of the plant growth regulator trinexapac-ethyl reduces plant height and ear insertion height with its increasing doses, allowing the use of a higher plant density.

The interaction between plant population and application of trinexapac-ethyl favors corn yield.

The highest grain yields were observed in the combinations of 93.40 thousand plants $\mathrm{ha}^{-1}$ with a dose of $176.00 \mathrm{~g} \mathrm{ha}^{-1}$ for the hybrid $2 \mathrm{~B} 710 \mathrm{HX}$ $\left(11,857.70 \mathrm{~kg} \mathrm{ha}^{-1}\right)$ and 92,20 thousand plants ha $\mathrm{ha}^{-1}$ with a dose of $251.00 \mathrm{~g} \mathrm{ha}^{-1}$ for the hybrid Status TL $\left(11,731.60 \mathrm{~kg} \mathrm{ha}^{-1}\right)$.

\section{REFERENCES}

ALVAREZ, R. C. F.; CRUSCIOL, C. A. C.; NASCENTE, A. S. Produtividade de arroz de terras altas em função de reguladores de crescimento. Revista Ceres, v. 61, n. 1, p. 42-49, 2014.

ARF, O. et al. Uso de etil-trinexapac em cultivares de arroz de terras altas. Pesquisa Agropecuária Tropical, v. 42, n. 2, p. 150-158, 2012.

ARGENTA, G.; SILVA, P. R. F.; SANGOI, L. Arranjo de plantas em milho: análise do estado-daarte. Ciência Rural, v. 31, n. 6, p. 1075-1084, 2001.

COELHO, A. M. Nutrição e adubação do milho. Sete Lagoas: Embrapa Milho e Sorgo, 2006. 10 p. (Circular Técnica, 78).

CONTRERAS, R. L. G. et al. Effects of trinexapacethyl on different wheat varieties under desert conditions of Mexico. Agricultural Sciences, v. 3, n. 5 , p. $658-662,2012$.

DAVIES, P. J. The plant hormones: their nature, occurrence, and functions. In: DAVIES, P. J. Plant Hormones: biosynthesis, signal transduction, action. 3. ed. New York: Springer, 2010. cap. 1, p. 1-15.

EMPRESA BRASILEIRA DE PESQUISA AGROPECUÁRIA - EMBRAPA. Sistemas de Produção: Cultura do milho. 2011. Disponível em: $<$ https://ainfo.cnptia.embrapa.br/digital/bitstream/ item/27037/1/Plantio.pdf $>$. Acesso em: 02 mai. 2018 .

ESPINDULA, M. C. et al. Effect of nitrogen and trinexapax-ethyl rates on the spad index of wheat leaves. Journal of Plant Nutrition, v. 32, n. 11, p. 1956-1964, 2009.
ESPINDULA, M. C. et al. Rates of nitrogen and growth retardant trinexapac-ethyl on wheat. Ciência Rural, v. 41, n. 12, p. 2045-2052, 2011.

FRANCIS, C. A.; RUTGER, J. N.; PALMER, A. F. E. A. Rapid method for plant leaf area estimation in maize (Zea mays). Crop Science, v. 9, n. 5, p. 537539,1969

GALVÃO, J. C. C. et al. Sete décadas de evolução do sistema produtivo da cultura do milho. Revista Ceres, v. 61, sup., p. 819-826, 2014.

KAMRAM, M. et al. Effect of paclobutrazol, a potential growth regulator on stalk mechanical strenght, lignin accumulation and its relation with lodging resistance of maize. Plant Growth Regulation, v. 84, n. 2, p. 317-332, 2018.

KAPPES, C. et al. Arranjo de plantas para diferentes híbridos de milho. Pesquisa Agropecuária Tropical, v. 41, n. 3, p. 348-359, 2011.

KASELE, I. N. et al. Ethephon alters corn growth, water use, and grain yield under drought stress. Agronomy Journal, v. 86, n. 2, p. 283-288, 1994.

LEOLATO, L. S. et. al. Growth Regulator and maize response to the increases in plant density. Pesquisa Agropecuária Brasileira, v. 52, n. 11, p. 997-1005, 2017.

LINZMEYER JUNIOR, $R$. et al. Influência de retardante vegetal e densidades de plantas sobre $\mathrm{o}$ crescimento, acamamento e produtividade da soja. Acta Scienciarum Agronomy, v. 30, n. 3, p. 373-379, 2008 .

MENDES FAGHERAZZI, M. et al. Phenological sensitivity of two maize cultivars to trinexapac-ethyl. Planta Daninha, v. 36, s/n., e018154739, 2018.

PENCKOWSKI, L. H.; FERNANDES, E. C. Utilizando regulador de crescimento na cultura do trigo: aspectos importantes para garantir bons rendimentos. 3. ed. Castro, PR: Fundação ABC. 2010. 68 p.

PRICINOTTO, L. F.; ZUCARELI, C. Paclobutrazol no crescimento e desenvolvimento produtivo da soja sob diferentes densidades de semeadura. Revista Caatinga, v. 27, n. 4, p. 65-74, 2014.

PRICINOTTO, L. F. et al. Trinexapac-ethyl in the vegetative and reproductive performance of corn. African Journal of Agricultural Research, v. 10, n. 14, p. $1735-1742,2015$.

RADIN, B. et al. Evapotranspiração da cultura do milho em função da demanda evaporativa 
atmosférica e do crescimento das plantas. Pesquisa Agropecuária Gaúcha, v. 9, n. 1, p. 7-16, 2003.

REUNIÃO DA COMISSÃO BRASILEIRA DA PESQUISA DE TRIGO E TRITICALE - RCBPTT. Informações técnicas para trigo e triticale - Safra 2017. Londrina, PR: Embrapa, 2017. 240 p.

RITCHIE, S. W.; HANWAY, J. J.; BENSON, G. O. Como a planta de milho se desenvolve. Piracicaba, SP: Potafos, 2003. 20 p.

SANGOI, L. Understanding plant density effects on maize growth and development: an important issue to maximize grain yield. Ciência Rural, v. 31, n. 1, p. 159-168, 2001.

SANGOI, L. et al. Bases morfológicas para maior tolerância dos híbridos modernos de milho a altas densidades de plantas. Bragantia, v. 61, n. 2, p. 101$110,2002$.

SANGOI, L.; SILVA, P. R. F. Alta densidade e espaçamento entre linhas reduzido em milho. Revista Cultivar, v. 87, n. 3, p. 10-15, 2006.

SANGOI, L. et al. Desenvolvimento e exigências climáticas da planta de milho para altos rendimentos. Lages, SC: Graphel, 2007.95 p.

SANGOI, L. et al. Perfilhamento e prolificidade como características estabilizadoras do rendimento de grãos do milho, em diferentes densidades. Revista Brasileira de Milho e Sorgo, v. 9, n. 3, p. 254-265, 2010.

SANGOI, L. et al. Senescência foliar e resposta de híbridos de milho liberados comercialmente para cultivo em diferentes épocas ao adensamento. Revista Brasileira de Milho e Sorgo, v. 12, n. 1, p. 21-32, 2013.

SANTOS, H. G. et al. Sistema Brasileiro de Classificação de Solo. 3. ed. Brasília, DF: Embrapa, 2013. 353 p.

SILVA, A. F. et al. Produtividade de híbridos de milho em função do espaçamento e da população de plantas em sistema de plantio convencional. Revista Brasileira de Milho e Sorgo, v. 13, n. 2, p. 162-173, 2014.

SOUZA, C. A. et al. Arquitetura de plantas e produtividade de soja decorrente do uso de redutores de crescimento. Bioscience Journal, v. 19, n. 3, p. 634-643, 2013.

ZAGONEL, J.; FERNANDES, E. C. Doses e épocas de aplicação de redutor de crescimento afetando cultivares de trigo em duas doses de nitrogênio. Planta Daninha, v. 25, n. 2, p. 331-339, 2007.

ZAGONEL, J.; FERREIRA, C. Doses e época de aplicação de regulador de crescimento em híbridos de milho. Planta Daninha, v. 31, n. 2, p. 395-402, 2013.

This work is licensed under a Creative Commons Attribution-CC-BY https://creativecommons.org/licenses/by/4.0/ 